\title{
'Hopeful' directions for writing centres in South Africa: From safe spaces to transitional sites of articulating practice
}

\author{
Pamela Nichols \\ Wits Writing Centre, University of the Witwatersrand, South Africa \\ E-mail: pamela.nichols@wits.ac.za
}

\begin{abstract}
I shall orientate the discussion of the directions of writing centres in South Africa around two beginnings. The first is the 1995 conference at the University of the Western Cape at which representatives from universities across the country discussed the new (in South Africa) idea of the writing centre and its local, varied applicability, and the second is the continuing student protests since 2015, which demand a re-theorising of the role of writing centres. This retheorising requires a revisiting of explicitly anti-exclusionary practice and the theory of what we do when we listen. Using the work of Lisa Delpit (1995) and her reflections on how the American system of education has failed the majority of African Americans and other 'outside' groups, I shall investigate her understanding of listening and connectedness for greater pedagogic inclusiveness. Then through considering the work of Nancy Grimm (1999), I shall discuss the theory of the transitional space, which resonates with Delpit's conclusions and which explicitly seeks not to normalise or erase difference but rather to find its articulation. Lastly, I shall evoke James Baldwin as a master articulator of difference, as a writer who expresses a fluidity of subjectivity and as a cultural alternative to explicitly ideological and political responses to a time of crisis. The current resurgence of Baldwin studies and the success of the recent documentary based entirely on Baldwin's words (Peck 2017) suggest the appeal of Baldwin's voice now as someone who moves us beyond labels and makes us see each other and see ourselves as others see us.
\end{abstract}

Keywords: listening, transformation, transitional spaces, writing centres, writing intensive pedagogy

\section{Introduction}

All histories are at one level histories of the present. This discussion of writing centres in South Africa is focused by the memory of the lump of concrete that shattered one of the Wits Writing Centre windows last year and by recent accounts by faculty members of performances of resistance in classrooms and lecture halls that have closed down discussion. Since the student protests that began in late 2015, everyone in South African higher education has had to rethink the need for and the meaning of transformation, and our individual and professional roles within the university. Any complacency that we might have had has been shattered as our environment has been severely disrupted. I shall argue that writing centres can offer a limited but effective 
strategy for finding ways to think in this time of turmoil, not primarily through practising the art of the contact zone (which has been our traditional theoretical location) but rather through developing the discipline, skills, temporary containment and thinking through of multiple ideas and arguments in the transitional space.

I shall organise this discussion of writing centres in South Africa around two moments: the 1995 conference held by the University of the Western Cape and the University of Cape Town at which representatives from universities across the country discussed the new (in South Africa) idea of the writing centre and its local, varied applicability; and the recent and continuing large-scale student protests, which demand a re-theorising of the role and creative possibilities of writing centres.

The idea of the writing centre originated in the United States of America. It developed from progressive pedagogical movements, ${ }^{1}$ yet in its transplantation to South Africa, some of its democratising philosophy appears to have been unrealised. If we revisit our beginnings, I think that we can adjust our trajectories. A re-reading of two classic contemporary American texts, one on anti-racist practice in American education and the other on the theory and discipline of the writing centre as a consultation space, offers a timely opportunity for the revision of writing centre principles of inclusion and listening. Drawing on the arguments of Lisa Delpit ${ }^{2}$ (1995) on how the American system of school education failed the majority of African Americans and other 'outside' groups, I shall examine her particular understanding of listening and connectedness for greater pedagogic inclusiveness. Then through a consideration of the work of Nancy Grimm ${ }^{3}$ (1999), I shall consider the theory of the transitional space, which explicitly seeks not to normalise or erase difference but rather to find its articulation. Finally, I shall consider James Baldwin as a master articulator of difference, as a writer who exhibits a fluidity of subjectivity and as a cultural alternative to explicitly ideological and political responses to a time of crisis. The current international resurgence of Baldwin studies and the success of the recent documentary based entirely on Baldwin's words (Peck 2017) suggest the particular power of Baldwin's voice now, as someone who moves us beyond labels and helps us to see each other and to see ourselves as others see us.

The 1995 conference was an important landmark for South African writing centres because it drew together people from across the country with very similar ideas at what was widely perceived as a time of new beginnings. The writing centres at the University of the Western Cape, the University of Cape Town and the (then) Cape Peninsula Technikon had been recently established. Participants at the conference were convinced that writing centres were an effective means of promoting access, of avoiding the stigma and belittling act of remediation, and of promoting mutually supportive networks of students within the university. The University of the Western Cape/University of Cape Town conference established what has become a feature of South African writing centres: a generous network of colleagues across universities who

\footnotetext{
See Summerfield (1988).

2 Lisa Delpit received the prestigious MacArthur 'genius' award in 1990, has written extensively on schools and teacher training and is currently Director of the Center for Urban Educational Excellence at Florida International University and Fenton G Clark Distinguished Professor at Southern University, Baton Rouge.

3 Nancy Maloney Grimm has directed the Michigan Technical University Writing Center since 1985, has been the executive secretary of the International Writing Centers Association and is co-editor of The Writing Center Journal.
} 
support each other and the work of the writing centres, even when their home institutions are less convinced of the significance of their role.

The application of the idea of the writing centre took different forms at different universities and inevitably interacted with pre-existing ideas of academic development, local, national and international. It is beyond the scope of this paper to describe the varied institutional differences that constrained writing centre development. Such research is bound to be contentious and involves interrogating acknowledged and unacknowledged influences (see Jansen 2009; Nichols 2014, 2016). Rather than excavating problems of stasis, this paper seeks new, positive directions, echoing the 2017 National Arts Festival's theme of creative disruption.

The American idea of writing centres, as John Trimbur (2010:89) observes, has always emphasised increasing access and participation:

In a sense, of course, social justice and the democratization of higher education have always been parts of the mission of writing centers, from the GI bill of the postwar period, to open admissions in the 1970s, to the latest struggles to defend access in the CUNY schools and elsewhere.

Longstanding theoretical aspects of the writing centre mission in the United States included non-directive tutoring (Brooks 2001; Bruffee 2001), an emphasis on the writer rather than the writing (North 1984) and the addressing of a non-member of an 'in-group' with respect to communication in an academic context (DiPardo 1993; Boquet 2002). I have also argued that the Freedom Schools of the Civil Rights Movement through their use of open-ended dialogue offered, and still offer, important resources for democratic writing centres (Nichols 2016). In the early years of South African democracy, American ideas of the democratising role of writing centres seemed to offer rich potential to support the transformation of teaching and learning practices within existing universities.

John Trimbur in his foreword to Changing spaces: Writing centres and access to higher education (Archer and Richards 2011) - the first book about writing centre practice in South Africa that brought together contributions from seven institutions - expressed his enthusiasm for the role that writing centres in South Africa could play in the transformation of higher education. All of the new writing centres appeared to be aware of issues of identity, power and access and of how the practice of the writing centre consultation might enable engagement with students where they begin: help students surface tacit knowledge, build on that knowledge and find ways to position their understanding against others. The idea of the writing centre as a safe space in otherwise culturally hostile or alienating environments was common in this first collection of essays on South African writing centres and frequently found expression in their physical appearances, which were designed to look welcoming and to encourage students to relax and to think. Some writing centres included creative writing as a way of ensuring the presence of cultures and aspects of identity that were excluded by hegemonic academic discourse. As a contact zone ${ }^{4}$ for students and between the writing centre itself and faculty, the writing centre also offered the potential for research that could inform and influence mainstream teaching. The student tutor consultants were understood to be potential future scholars who

4 Mary Louise Pratt's famous anthropological description of the contact zone has been much used in writing centre theory. For a South African application, see Daniels and Richards (2011). 
were learning to develop both their own responsible, innovative intellectual culture and sustainable networks with other student tutors.

Through writing groups and writing circles, writing centres and their affiliates promoted a selfsustained and self-directed writing culture among both students and scholars. ${ }^{5}$ Writing centres sometimes became involved in outreach work, helping to promote literacy and freer imaginations. Writing centres were also often understood as multilingual sites where meaning was reached through moving between languages. This was particularly the case at Stellenbosch University where multilingualism was built into the mandate of the Writing Lab. The creation of community in a peripheral centre that encouraged listening, engagement and rehearsal was the generating idea of the Wits Writing Centre, which was mirrored in a national network, particularly supported by the Western Cape writing centres and by the Stellenbosch University Writing Lab, which fostered intra-university community though indabas, through drawing on each other's expertise and through the sharing of international visitors. Stellenbosch also pioneered the creation of an annual conference specifically designed for developing the student consultants' expertise and their own national network.

Over the next two decades, the sense of a national community of writing centre practitioners grew stronger, even though the paths taken by various writing centres grew increasingly diverse, often shaped by the local institutional cultures of the universities in which they were embedded. However, irrespective of institutional location, the national student protests in 2015 and 2016 challenged everyone in South African higher education to rethink ideas of community and to interrogate the impact of racial constructs on those definitions. ${ }^{6}$

\section{Listening and connectedness for greater pedagogic inclusiveness}

The effects of racially derived cultural constructs on the learning results of black children in American schools and the need to create education spaces that speak to the strengths of learners rather than focusing on perceived weaknesses have been central to the work of a leading scholar of education and access, Lisa Delpit. Her arguments on the issues of invisibility and 'disidentification' experienced by many black and minority students on American campuses have significant resonance in the current South African context. ${ }^{7}$

Delpit's classic 1995 book Other people's children: Cultural conflict in the classroom is frequently cited as a critique of a liberal, indirect process approach to the teaching of writing as opposed to an explicit teaching of skills. However, Delpit (1995:9) herself refutes such a reading:

- neither skills nor process, liberal nor conservative - is sufficient in and of itself, yet many educators insist on dichotomizing my ideas, making me a proponent or a detractor of one or other perspective.

5 See Nichols (2011) for writing groups among students and staff, and Chihota and Thesen (2014) for postgraduate writing circles.

6 For similar concerns in America, see Barron and Grimm (2002), Davila (2006), Greenfield and Rowan (2011) and Arao and Clemens (2013).

7 See, most recently, "Multiplication is for white people": Raising expectations of other people's children (Delpit 2012). 
Delpit's (1995:19) stated position is rather that "if minority people are to effect the change which will allow them to truly progress we must insist on 'skills' within the context of critical thinking". Reading Delpit against current realities in South African universities makes clear not only the need to be explicit about skills - within the context of critical thinking - but also the applicability to the South African cultural and historical context of her acute observations and analysis of and response to 'subtle racism'. Drawing on her own experience as a child when she realised that aspects of her home culture provoked remediation or were even taken as evidence of learning disability, Delpit (1995:73) "decided that any system that, in the name of education, did so much harm to children had to be changed". By 'subtle racism', Delpit (1995:113) refers to Benokraitis and Feagin's (1986) classification that distinguishes between 'overt' (most obvious), 'covert' (hidden, ill-meaning) and 'subtle' (unequal treatment that is visible but so internalised as to be considered normal).

The first step, therefore, is to look at the classroom in terms of power, in this case racialised power. ${ }^{8}$ Delpit (1995) writes that after we have admitted that issues of power are enacted in the classroom, we then have to identify the rules of participation in that culture of power, rules that are often invisible to those with power and that have to be learnt by those who are not participants in power. These micropolitics need to be surfaced so as to be negotiated and to be understood as arbitrary codes to be learnt by those who enter initially without power, not as a replacement for home culture but as an addition.

The surfacing of the codes of power, and the coaching of students so that they can speak and be heard, requires listening. This is listening from both sides, from the student and perhaps even more from the tutor, and it is a serious, difficult business.

To do so, takes a special kind of listening, listening that requires not only open eyes and ears, but open hearts and minds. We do not really see through our eyes or hear through our ears, but through our beliefs. To put our beliefs on hold is to cease to exist as ourselves for a moment - and that is not easy. It is painful as well, because it means turning yourself inside out, giving up your own sense of who you are, and being willing to see yourself in the unflattering light of another's angry gaze. It is not easy, but it is the only way to learn what it might feel like to be someone else and the only way to start a dialogue.

(Delpit 1995:47)

For Delpit, success in this sort of listening requires that we believe that people are expert in their own lives; we must not be quick to deny their interpretations; we must believe that they are rational beings; and we "must be vulnerable enough to allow our world to turn upside down in order to allow the realities of others to edge into our consciousness. In other words, we must become ethnographers in the true sense" (1995:47). This sort of listening takes courage and resilience for it is a listening that goes against the grain of hegemonic culture and requires us to hear that which might otherwise be silenced.

Apart from this two-way listening that turns us inside out, Delpit emphasises the need for connectedness in order to learn. Students, she observes, need to be connected to their meaning

8 In "Educating the citizen scholar in the South African writing class: Insights from three US writing teachers" (Nichols 2016), I also began with a framework for analysing the micropolitics of the South African writing class, but I was examining issues of authority and relationship to knowledge rather than considering directly racialised culture. Now I think that we must include a focus on the dynamics of racialised power. 
and not constantly be monitored for mistakes; they need to be connected to their languages, understanding academic English as an addition, not a replacement; they need to connect new knowledge to prior knowledge; they need to connect with each other and form cohorts; and, lastly, we as teachers need to connect with our students and know them ("In order to teach you, I must know you", Delpit writes (1995:183), quoting a North Alaskan educator). A similar approach has also informed the remarkable work of the Columbia University scholar Christopher Emdin on the role of hip hop culture in promoting school success amongst highly disadvantaged black and minority learners. ${ }^{9}$ The relevance of this connectedness for education in South Africa today could not be clearer.

Delpit drew her conclusions from her own experiences attending schools in Baton Rouge in the Deep South, from wider African American experiences and from her observations in Alaska and Papua New Guinea. Her pedagogy is derived from an ethnological perspective, from minority experiences in the United States and from cultures very different from South Africa. Yet, her call for difficult listening and the multiple benefits of recognising the importance of different forms of connection in learning are relevant foci for addressing our own subtle and stubborn forms of racism so that we too can work towards her belief that

individuals have the ability to transform dominant discourses for liberatory purposes to engage in what Henry Louis Gates calls "changing the joke and slipping the yoke," that is, using European philosophical and critical standards to challenge the tenets of European belief systems.

(Delpit 1995:162)

Listening and connectedness are features of writing centre work that we can bring to the fore in promoting more inclusive teaching. In fact, these activities and principles are particularly suited to writing centre work. They are harder to enact in a lecture hall, though creating these spaces for listening, connecting and thinking can be built into mainstream courses in the same way that aspects of writing centre work can emerge as part of consultations during office hours, in group work, in writing groups and between tutors, students and lecturers in writing intensive courses. ${ }^{10}$

\section{The transitional space}

Nancy Grimm, a leading American writing centre scholar, offers us a re-theorising of this space of reflection and ideas of how to ensure a maximum chance of promoting constructive new thinking. She specifically avoids the idea of safe spaces that can be understood as exerting what Foucault called 'pastoral power' so as to normalise students. Rather, she evokes the concept of a transitional space as a way to expand thought through unafraid self-directed intellectual exploration. Transitional spaces are about listening and connectedness and offer principles and disciplines to ensure both.

The publication of Grimm's book Good intentions: Writing centre work for postmodern times served as a warning to American writing centres, as it does to South African writing centres

\footnotetext{
9 See Urban science education for the hip hop generation (Emdin 2010) and For white folk who teach in the hood ... and the rest of y'all too: Reality, pedagogy and urban education (Emdin 2016). I explore elsewhere the fungibility of these ideas in South Africa.

10 See for example Scott (2015).
} 
two decades later. Like Delpit, Grimm's (1999:119) concern is to make us revise our understanding of community so as to not exclude:

Granting membership to students means putting aside the missionary narrative of literacy, the modernist belief that we can all come together through a purified standard language. Rather, we come together to alter our perspectives in order to perceive another's world.

It is striking that both Delpit and Grimm are making the same commonsensical but profoundly anti-hegemonic point:

O wad some Power the giftie gie us

To see oursels as ithers see us!

(Robert Burns, “To a louse: On seeing one on a lady’s bonnet, at church”, 1786)

Like Delpit, Grimm (1999:xii) begins by acknowledging power, this time as a fault line within the idea of literacy itself, which both liberates and dominates. "While literacy is supposed to guarantee access to education and jobs, at the same time it acts as a gatekeeper, preventing access and demanding submission to a standard in exchange for passage." Again, the only way out of this one-way passage is to listen and to reconsider the nature of this supposedly simple act. ${ }^{11}$ Grimm (1999:69) quotes Heidegger to describe authentic listening as "a 'dwelling' in another's thought with part of our mind suspended, recognizing 'that we share in both the problem and the solution without being able to escape into neutral and unrelated spaces"". This listening is not so much a controlled intellectual activity as an experience: "It is almost as though in order to listen one had to 'become' different, since it is not so much a question of grasping concepts or propositions as of attempting an experience" (Fiumara 1990 quoted in Grimm 1999:69). From and within this experience, our subjectivity is changed, encouraged to become web-like, multiple, fluid. Grimm is of course describing the ideal of writing centre practice, the listening that happens in the one-to-one consultation, but she re-theorises it as the transitional space that explicitly frames ways for the self to reconcile itself with others.

Using the work of Jane Flax ${ }^{12}$ (1993), a leading feminist scholar and practising psychoanalyst, Grimm explores the idea of transitional spaces as the opportunity to think away from external and internal pressures. She describes transitional spaces as opportunities to embrace uncertainty, ambivalence and multiplicity. The success of such spaces depends on our ability to be fluid multiple subjects, to resist anxieties that press us into binary thinking and instead to creatively transform our thought through the work of symbolisation. In this basic space of learning, a child plays with possibilities as a person throughout her or his life reconciles her- or himself with others. At the same time, it is a political space and connected to the process of justice because subjectivity is itself political. In the words of Flax, quoted by Grimm (1999:111): "Since discussions about justice implicitly or explicitly assume and generate

11 In "Heeding the corpse: The writing centre and the need to listen" (Nichols 2011), I was also writing about the underplayed but vital need to listen, especially in a country with unacknowledged trauma, and its application to writing centre praxis.

12 Flax is also a scholar of race; see Flax (2010). 
assumptions about who 'we' are and why we are living together, discourse about justice cannot do without concepts of subjectivity." 13

Flax describes four sequential components of the transitional space:

1. Reconciliation - seeing all sides, creating a unity of differences rather than annihilating opposites and distinctions.

2. Reciprocity - the sharing of authority and decision, the resisting of false accommodation to ill-fitting demands and the reciprocal understanding of relationship between social forces and individual problems.

3. Recognition - the acceptance of differences and identifying with them.

4. Judgment - a process of balancing and proportion that needs logic, objectivity and empathy, that requires us to move back and forth between multiple realities and that "encourages us to tolerate ambiguity and ambivalence without losing a sense of individual location and responsibility"

(Adapted from Flax 1993:78).

The method resembles the idea of motivational listening ${ }^{14}$ in the health sciences that allows the patient to control the what, why and how of change while the health worker controls the general direction of the consultation. The greatest challenge for new practitioners of this method, according to Rollnick et al. (2010), is resisting the 'righting reflex' and instead allowing the patient to take authority over the content of the session, as suggested by the need for reciprocity above. The commonality of method in the fields of health sciences and education reinforces a perceived ethical need for answers and change to be motivated and found by individuals, not simply prescribed by institutional authorities or prevailing ideologies. Transitional spaces in times of difficult conversations reinforce the discipline of listening fully to another person, of not reducing individuals, for example, to systems of social advantage, but rather looking for connections between one person and another that are conducive to mutual growth. ${ }^{15}$

Grimm's idea of the transitional space transposed to a writing centre and to the university allows for the questioning of norms about what and how we know and assume. It challenges the confidence derived from naturalising the ways of the dominant group. It extends and preserves the interplay of difference and similarity. It brings life experience into negotiation with others and allows for two-way listening to facilitate new articulations, and contingent, time-bound connection of ideas. As Rouse and Katz (2003) describe the democratic writing classroom as a place of situated knowledge, of parallel stories rather than directive top-down teaching of a single story, the transitional space allows for parallel truths to be recognised and explored and articulated. In this way, Grimm (1999:98) suggests that the art and discipline of the transitional

13 See Barcheisi (2016) for critiques of un-interrogated subjectivity around the idea of 'we' in South Africa, and Carter (2009) for the writing centre paradox within the logic of plurality. Both writers show the need for a highly disciplined listening lest progressive ideas slip into pre-existing, non-progressive habits.

14 Rollnick et al. (2010).

15 See, for example, Asam (2015) for a discussion on 'call-out culture'. 
space allow writing centres to contribute to social transformation and to promote voices that can question the norm:

As sites of articulating practice, writing centres will be less tuned to helping writers master community conventions and more tuned to developing the capacity of staff to entertain multiple perspectives, to resist binary alignments, to think in systematic and complicated ways about literacy practices, to manage emotional reactivity to hot issues, to gather evidence, and to explore the contradictions in literacy work.

\section{The articulation of difference}

Writing centres and literacy work have long insisted that talk can promote learning and the weaving of the web of meaning. As Moffet wrote in 1968 describing the discussion between child and adult, "The cues for his next line are not what his interlocutor said, but what he himself just said" (quoted in Britton 1982:166). Similarly, Basil Bernstein insisted in 1971 that "[a] university is a place organized around talk" (quoted in Rosen 1972:22). ${ }^{16}$ Writing centres have always worked with the idea of people talking themselves into literacy through the centrality of the one-to-one consultation. The transitional space, drawing on insights from psychoanalysis, heightens this discipline through a focused awareness on the care of listening to and hearing the non-hegemonic, thereby fostering recognition and judgment and promoting articulation. From this perspective, writing centre work can contribute to revisions of the curriculum through reconnection with estranged students through their articulation of points of view that have been submerged by dominant thinking.

This power of articulation was in my mind as I listened to the voice of James Baldwin in Raoul Peck's documentary I am not your Negro (2016). Peck uses footage of Baldwin speaking and a voice-over by Samuel L. Jackson reading from Baldwin's unpublished memoir on Medgar Evers, Dr Martin Luther King and Malcom X, "Remember this house". All words in the film are Baldwin's. It struck me as I watched this intense film that Baldwin offered a third intellectual position, in comparison to Dr King's belief in nonviolence and Malcom X's call for resistance (positions that as Baldwin says in the film were in any case becoming closer to each other in their understanding of the hostility of the wider society and the implications for the strategy of the freedom movement). Baldwin's view was that of the outsider and writer, the listener and the articulator. While his sexuality is not centre stage in the documentary, nevertheless his position is queered, off-centre. He exhibits a fluidity of subjectivity, commenting at one point in the film, almost in despair, "I am not a racist", which speaks directly to current realities. In this film, seamlessly, we see footage from the Black Lives Matter movement. The current resurgence in Baldwin studies suggests that his voice is addressing contemporary feelings and frustrations. ${ }^{17}$ Baldwin, according to Raoul Peck, was a man who never wanted to be labelled by anybody and yet continually helped others, including the director of the documentary, to find their own identity and to question ideas of who they were meant to

16 I explore elsewhere the role of Bernstein's ideas in the wider international sociology of education and the implications for the practice of the writing centre.

17 See Pinckney (2017). There has been a renewed discussion of Baldwin's 'literary genius and political engagement' (in the words of Cornel West) in the light of the debates triggered by Coates' Between the world and me (2015) and the comparisons between Coates and Baldwin. For a prescient discussion, see Gates (1992), and for an assessment of the current debate, see Green (2017). 
be. ${ }^{18}$ In The fire next time Baldwin (1963) wrote about the pain of not being heard, and his cry echoes still:

Yes, it does indeed mean something - something unspeakable - to be born, in a white country, an Anglo-Teutonic, antisexual country, black. You very soon, without knowing it, give up all hope of communion. Black people, mainly, look down or look up but do not look at each other, not at you, and white people, mainly, look away.

"Yet, because I am alive, I must hope," he says in the film, and because readers can recognise and identify with his words, they can start to name their feelings, think further and gain more choice over their actions.

This American 'burning house' is not South Africa, and yet it possesses considerable resonance for a new country in which the majority are black but where that understanding remains partial. In the words of Njabulo Ndebele (2017:16):

It is time to realize that the norm of human presence in South Africa is 'black' That recognition is central to understanding where the real agency for shaping the future is located, so that 'blackness' becomes so normal it ceases to exist.

Baldwin's voice in the burning house offers a cultural rather than an explicit political response. His voice, born of a fluid subjectivity, reaches over decades to help us, whether in the Black Lives Matter movement or in the Fallist movement, to think about who we are and who we are together.

\section{Conclusion}

The idea of the transitional space, crafted in writing centres and transposed when possible into mainstream teaching, enables us to symbolise and to make meaning from the interaction of the self with others. Within the Wits Writing Centre, it is no coincidence that since the protests began, record numbers of students have applied to be consultants, many of them highly aware of the issues of the protests, and that a particularly large number of students have registered for consultations, as has been the case at writing centres across the country. In part, this has reflected a willingness by students to confront the distress that they face in coming to terms with the institutional and pedagogic practices of the university. This willingness is illustrated by a recent striking example, this time from mainstream teaching. In a feedback session of a writing intensive initiative for social work first years, students wept as they explained to their writing fellow tutor their assumption that their home languages and cultures had no connection to what they believed to be the cast-iron institutional requirements of standard academic English. Writing intensive courses are existing discipline-specific courses that have been adapted to foreground critical thinking goals, and in their recent development in South Africa, they have been pioneered and supported by writing centres and writing fellow tutors assigned to writing intensive lecturers (Nichols 2017). Writing intensive courses and programmes represent the extension of writing centre pedagogy into mainstream teaching through the creation of opportunities for formalised listening and responding to developing thinking in mainstream classes. The increasing numbers of staff, tutors and students who are adopting the

18 Raoul Peck (2017), CBC radio interview. 
writing intensive approach suggest the perceived relevance of progressive writing centre pedagogy to initiating an ongoing transformation of curricula.

Instead of waiting for the throwing of concrete lumps at writing centre windows or the burning of libraries of social work books, employing the pedagogy of transitional spaces offers a difficult but hopeful way of learning more about what people are thinking and feeling and then thinking further about how to think and to act, individually and together, in a too easily violent world. ${ }^{19}$

\section{Acknowledgements}

Many thanks to Dr John S. Rowett for his extremely helpful comments on the draft of this paper.

\section{References}

Arao, B. and C. Clemens. 2013. From safe spaces to brave spaces: A new way to frame dialogue and diversity and social justice. In L. Landreman (ed.) The art of effective facilitation: Reflections from social justice educators. Sterling, VA: Stylus Publishing. pp. 135-150.

Archer, A. and R. Richards (eds.). 2011. Changing spaces: Writing centres and access to higher education. Stellenbosch: SUN PReSS.

Asam, A. 2015. A note on call-out culture. Available online: http://www.filmsforaction.org/articles/anote-on-callout-culture/ (Accessed 10 June 2017).

Baldwin, J. 1963. The fire next time. New York: First Vintage International, Random House.

Barcheisi, F. 2016. The problem with 'we': Affiliation, political economy, and the counter history of non-racialism. In S. Walsh and J. Soshe (eds.) Ties that bind: Race and politics of friendship in South Africa. Johannesburg: Wits University Press. pp. 125-165.

Barron, N. and N. Grimm. 2002. Addressing racial diversity in a writing center: Stories and lessons from two beginners. The Writing Center Journal 22(2): 55-83.

Benokraitis, N. and J. Feagin. 1986. Modern sexism: Blatant, subtle, and covert discrimination. Englewood Cliffs, NJ: Prentice-Hall.

Boquet, E.H. 2002. Noise from the writing center. Logan, UT: Utah State University Press.

Britton, J. 1982. Language and learning. Middlesex: Penguin.

Brooks, J. 2001. Minimalist tutoring: Making the student do all the work. In R.W. Barnett and J.S. Blummer (eds.) The Allyn and Bacon guide to writing center theory. Boston, MA: Allyn and Bacon. pp. 219-224.

19 I am suggesting a process rather than a reachable answer, a pursuit of the "chimes of freedom flashing", to quote Bob Dylan's song. See Grutsch McKinney (2013) for the dangers of a single "writing centre grand narrative'. 
Bruffee, K. 2001. Peer tutoring and the 'conversation of mankind'. In R.W. Barnett and J.S. Blummer (eds.) The Allyn and Bacon guide to writing center theory. Boston, MA: Allyn and Bacon. pp. 206-218.

Carter, S. 2009. The writing center paradox: Talk about the legitimacy and the problem of institutional change. College Composition Communication 61(1): 133-152.

Chihota, C.M. and L. Thesen. 2014. Rehearsing the 'postgraduate condition' in writers' circles. In L. Thesen and L. Cooper (eds.) Risk in academic writing: Postgraduate students, their teachers and the making of knowledge. Bristol: Multilingual Matters. pp. 131-147.

Coates, T-N. 2015. Between the world and me. New York: Speigel and Grau.

Daniels, S. and R. Richards. 2011. "We're all in this thing together": An equitable and flexible approach to language diversity in the Stellenbosch University Writing Lab. In A. Archer and R. Richards (eds.) Changing spaces: Writing centres and access to higher education. Stellenbosch: SUN PReSS. pp. 33-44.

Davila, B. 2006. Rewriting race in the writing center. The Writing Lab Newsletter 31(1): 1-5.

Delpit, L. 1995. Other people's children: Cultural conflict in the classroom. New York: The New Press.

Delpit, L. 2012. "Multiplication is for white people”: Raising expectations for other people's children. New York: The New Press.

DiPardo, A. 1993. A kind of passport: A basic writing adjunct program and the challenge of student diversity. Urbana, IL: National Council for Teachers in Education.

Emdin, C. 2010. Urban science education for the hip hop generation. Boston, MA: Sense Publishers.

Emdin, C. 2016. For white folks who teach in the hood ... and the rest of y'all too. Boston, MA: Beacon Press.

Flax, J. 1993. Disputed subjects: Essays on psychoanalysis, politics and philosophy. New York: Routledge.

Flax, J. 2010. Resonances of slavery in race/gender relations 2010: Shadow at the heart of American politics. New York: Palgrave MacMillan.

Gates, H.L. 1992 (2013). From the stacks: “The fire last time". The New Republic, 1 June. Available online: https://newrepublic.com/article/114134/henry-louis-gates-james-baldwin-fire-last-time (Accessed 10 September 2017).

Green, C. 2017. Re-making relations: Reading Ta-Nehisi Coates beyond James Baldwin. Assay: A Journal of Nonfiction Studies 3(2.) Available online: http://www.assayjournal.com/charles-greenremaking-relations-8203reading-ta-nehisi-coates-beyond-james-baldwin-32.html

(Accessed 12 July 2017).

Greenfield, L. and K. Rowan. 2011. Writing centers and the new racism: A call for sustainable dialogue and change. Logan, UT: Utah State University Press.

Grimm, N.M. 1999. Good intentions: Writing center work for postmodern times. Portsmouth, NH: CrossCurrents, Heinemann.

Grutsch McKinney, J. 2013. Peripheral visions for writing centers. Logan, UT: Utah State University Press. 
Jansen, J.D. 2009. Knowledge in the blood: Confronting race and the apartheid past. Stanford: Stanford University Press.

Ndebele, N.S. 2017. They are burning memory! A study of intergenerational dissonance. New Agenda 2017(64): 13-17.

Nichols, P. 2011. Student culture and cultural change: A manifesto for writing praxis in a South African writing centre. In A. Archer and R. Richards (eds.) Changing spaces: Writing centres and access to higher education. Stellenbosch: SUN PReSS. pp. 19-31.

Nichols, P. 2014. Heeding the corpse: The writing centre and the need to listen. South African Journal of Higher Education 28(3): 894-906.

Nichols, P. 2016. Educating the citizen scholar in the South African writing class: Insights from three US writing teachers. In I.K. Nwankwo, J. Hou and J. Cohen-Cruz (eds.) Globally Engaged Pedagogy, Research, and Creative Practice in Public: A Journal of Imagining America. Syracuse: Syracuse Press. 3(2). Available online: http://public.imaginingamerica.org/blog/article/educating-the-citizen-scholarin-the-south-african-writing-class-insights-from-three-us-writing-teachers/ (Accessed 5 June 2017).

Nichols, P. 2017. Writing democracy: From writing centres to writing fellows to writing intensive courses in a university-wide writing programme. In S. Clarence and L. Dison (eds.) Writing centres in higher education: Working in and across the disciplines. Stellenbosch: SUN PReSS. pp. 35-48.

North, S. 1984. The idea of the writing center. College English 46(5): 433-446.

Peck, R. 2016. I am not your Negro. Documentary based on James Baldwin's unfinished manuscript "Remember this house", directed by Raoul Peck. Paris: Wide House.

Peck, R. 2017. CBC radio interview: "Raoul Peck brings James Baldwin's powerful gaze to the big screen." Available online: http://www.cbc.ca/radio/q/friday-feb-24-2017-raoul-peck-reginald-edmundand-more-1.3995507/raoul-peck-brings-james-baldwin-s-powerful-gaze-to-the-big-screen-1.3995526 (Accessed 6 June 2017).

Pinckney, D. 2017. “Catching up to James Baldwin.” The New York Review of Books. May 25, 2017. Available online: http://www.nybooks.com/articles/2017/05/25/catching-up-to-james-baldwin/ (Accessed 28 May 2017).

Rollnick, S., C. Butler, P. Kinnersley, J. Gregory and B. Marsh. 2010. Competent novice: Motivational interviewing. British Medical Journal 340: 1242-1245. doi: 10.1136/bmj.c1900

Rosen, H. 1972. Language and class: A critical look at the theories of Basil Bernstein. Bristol: Falling Wall Press.

Rouse, J. and E. Katz. 2003 Unexpected voices: Theory, practice and identity in the writing classroom. Cresskill, NJ: Hampton Press.

Scott, A. 2015. Commenting across disciplines: Partnering with writing centers to train faculty to respond effectively to student writing. Journal of Response to Writing 1(1): 77-88.

Summerfield, J. 1988 (1995). Writing centres: A long view. In C. Murphy and J. Law (eds.) Landmark essays on writing centres. Davis, CA: Hermagoras Press. pp. 63-68.

Trimbur, J. 2010. Multiliteracies, social futures, and writing centres. Writing Center Journal 30(7): $88-91$. 